\title{
Soil Investments on Rented Versus Owned Plots: Evidence from a Matched Tenant-Landlord Sample in Malawi
}

\begin{tabular}{|c|c|c|}
\hline Jacob Ricker-Gilbert, PhD & Jordan Chamberlin, PhD & Joseph Kanyamuka, MS \\
(corresponding author) & Spatial Economist & Consultant \\
Associate Professor & Maize and Wheat & Lilongwe University of \\
Dept. of Agricultural & Improvement Center & Agriculture and Natural \\
Economics & (CIMMYT) & Resources \\
Purdue University & United Nations Avenue, & P.O. Box 219 \\
403 West State Street & Gigiri & Lilongwe, Malawi \\
West Lafayette IN. 47907 & P.O. Box 1041-00621 & jkanyamuka@ gmail.com \\
jrickerg@ @urdue.edu & Nairobi, Kenya & +265 995967065 \\
\hline $1(765) 494-4260$ & j.chamberlin@ cgiar.org & \\
\hline & +254207224468 & \\
\hline
\end{tabular}

JEL codes: D63, O12, Q15

Key words: land rental markets, soil quality, smallholder agriculture, sub-Saharan Africa 


\begin{abstract}
We use a unique dataset on matched tenant-landlord pairs in Malawi to compare decisions on smallholder plots that were rented versus those that were owner-operated. Controlling for household and rental-pair fixed effects, we found that some input use (e.g. hybrid maize seed) and soil fertility investments (e.g. manure, compost, minimum tillage) were higher on tenants' owneroperated plots than on their rented-in plots. Tenants were also less likely to use compost than their landlords. Landlords were less likely to rent out plots with fruit trees. Our results suggest that the expansion of farmland rental markets may exacerbate soil fertility maintenance concerns.
\end{abstract}

Appendix materials can be accessed online at: https://uwpress.wisc.edu/journals/pdfs/LE-98-1-10Ricker-Gilbert-app.pdf. 


\section{Introduction}

Recent growth of farmland rental markets in Sub-Saharan Africa (SSA) can be understood as part of an ongoing structural transformation process in the region. In the foundational discussions of this process, Johnston and Kilby (1965) explain how higher returns to labor in non-farm sectors induce an exodus of labor out of agriculture, with relatively more efficient farmers remaining in agriculture, expanding their capital and land endowments. This selfselection contributes to sectoral productivity gains, which are also driven by investments incentivized by increasing food demand and improving input market conditions. During this process, land transfers through rentals and sales should facilitate the reallocation of land resources to these more efficient farmers. ${ }^{1}$ For example, functioning land rental markets should allow tenants to expand area cultivated and bring more capital into the sector while at the same time potentially providing landlords with compensation for their land assets while they engage in other pursuits outside of agriculture.

Though most land cultivated by smallholders in SSA is managed in customary tenure systems where operators lack formal titles, recent evidence from the region suggests growth in land rental markets has been pronounced (Holden, Otsuka, and Place 2009; Chamberlin and Ricker-Gilbert 2016). Chamberlin and Ricker-Gilbert (2016) found that the percentage of households renting in land rose from $7.5 \%$ in 2002/03 to $15.4 \%$ in 2008/09 in Malawi and from $0.9 \%$ in $2001 / 02$ to $3 \%$ in $2012 / 13$ in Zambia. This suggests that growth in rental market participation has been taking place even in environments where tenure rights are still largely customary and tenure security is sometimes ambiguous.

At the same time, much of the region is facing a soil fertility crisis, with widespread soil nutrient losses occurring from year to year due to soil erosion and nutrient mining (Sanchez 
2002). The concurrent trends of increasing land rental participation and decreasing soil fertility are worth scrutinizing because there is some evidence to suggest that rented plots receive lower soil fertility enhancing investments than owner-cultivated plots. ${ }^{2}$ For example, Gavian and Fafchamps (1996), Jacoby and Mansuri (2008), Lovo (2016), and Muraoka, Jin and Jayne (2018) find that tenants are typically less likely to make soil-enhancing investments (such as animal manure application) on plots that they rent in compared to plots that they own and cultivate. This is a rational decision by tenants, given that rental contracts tend to be short-term in nature, while the soil fertility benefits of applying animal manure may take multiple years to be fully realized.

The present study adds to the literature on soil fertility and land renting using a unique plot-level data set from Malawi, collected in 2016, that matched tenants with landlords and collected soil samples on rented and owner-operated plots. ${ }^{3}$ Specifically, for each tenant we observed their rented-in plots (henceforth: tenant's rented-in plots) as well as all their owneroperated plots (tenant's owner-operated plots). One unique aspect of this dataset is that we also surveyed tenant's respective landlords, and hence we also observed the plots that the landlord did not rent out (landlord's owner-operated plots). The other novel feature of these data are that we took objective soil fertility measures including Nitrogen (N), Phosphorous (P), Potassium (K), $\mathrm{pH}$, organic matter, silt, clay, and sand on tenants' largest owner-operated plot, his or her and largest rented-in plot, along with the largest plot that was owner-operated by the landlord who owned the largest rented-in plot. ${ }^{4}$ This allowed us to expand our estimates of soil quality beyond the self-reported indicators that are asked to respondents in most studies (usually if the soil on their plot was of good, fair or poor quality). 
Using this unique dataset, we answered the following research questions related to land rental markets in SSA, which have been under-studied to date. First, did input use (eg: labor for weeding, applying herbicides, applying inorganic fertilizer, and planting hybrid maize) and soilfertility investments (eg: maize and legume intercropping, applying manure, applying green compost, using minimum tillage) differ on average among i) a tenant's rented-in plots, ii) a tenant's owner-operated plots and iii) the owner-operated plots of the tenant's landlord? As mentioned above, much of the previous literature indicated that tenants were less likely to make longer-term soil fertility investments on their rented-in versus owner-operated plots. However, landlord information was missing from these studies, limiting our insights into managerial changes that occur when land was transferred from landlords to tenants. As such, the present study seeks to understand how a tenant's input use and soil-fertility investments compared to his or her landlord's investments on his or her own plot. To our knowledge, this has not been empirically tested before using a matched tenant-landlord dataset.

Second, we ask: did landlords rent out plots that they believe to be of lower or higher soil fertility ex ante than those which they cultivated themselves, and how was this affected by the landlord's perception of tenure security on the plot? We might expect a landlord to have rented out land of lower soil fertility, ex ante, if he or she felt that such selection would not adversely affect rental receipts, or if he or she felt that renting out customary land may have increased the risk of having that land reallocated to someone else by a village leader. However, tenants generally have been found to be wealthier and better educated then landlords in our study area (Ricker-Gilbert et al. 2019). This suggests potential power imbalances, possibly giving tenants an advantage over landlords when selecting which plots to rent in. We therefore ask: were land rental transfers more likely to be from landlords' higher or lower quality plots? 
By combining a matched tenant-landlord dataset with both objective and subjective measures of soil fertility, the present article makes an important contribution to the land rental market and land tenure literature in SSA. Several earlier studies used matched tenant-landlord datasets, but with different objectives. For example, Deininger, Ali, and Alemu (2013) used a matched sample to estimate the relative differences in Marshallian efficiency between sharecropped plots, plots rented at a fixed rate, and owner-operated plots in Ethiopia. Bellemare (2012) used a matched sample from Madagascar to estimate how a landlord's perception of his or her tenure security affects the choice of contract offered to tenants. Ghebru and Holden (2014) used a matched landlord-tenant sample from Ethiopia to assess bargaining power, efficiency and distributional implications in tenant-landlord relationships. Ricker-Gilbert et al. (2019) use the same matched data set in Malawi as the present study to estimate efficiency and equity trade-offs between tenants and landlords when land rental arrangements are made. Ours is the first to use a matched tenant-landlord sample to estimate models related to land renting, soil fertility and other investments.

In addition, other studies have used objective measures of soil fertility to estimate how objective measures relate to farmers' subjective self-assessment of soil fertility. Both Berazneva et al. (2018) with data from Kenya and Tanzania, and Gourlay et al. (2017) with data from Ethiopia and Uganda, find that the link between objective (laboratory test-based) assessments and subjective (farmer reported) assessments of soil fertility is weak and that farmers base their subjective assessment on a plot's crop yield. To our knowledge, the present article is the first to use objective measures of soil fertility to understand how landlords use (or do not use) such information to make land use decisions. 
In order to answer our research questions, we estimated two econometric models. In the first model we regressed input use and soil fertility investments on land rental status for tenant's and landlord's plots, along with household and plot-level controls using linear models. The identification strategy for these models relied on the matched tenant landlord sample, allowing us to use rental-pair fixed effects (FE). Second, we estimated a linear probability model (LPM) for landlord households only and regress a binary variable $=1$ if the landlord rented out a specific plot on the following factors: i) objective soil fertility measures on the plot, ii) subjective soil fertility measures on the plot, iii) landlord perceptions of his our/her tenure security on the plot, and iv) investments made on the plot. In this model our identification strategy was based on the fact that we have soil samples for multiple plots within the landlord household (both rented-out plots and owner-cultivated plots). This allows us to use a within-household FE to control for unobserved factors associated with the landlord that may affect her rental decision. We also had a rich set of plot-level information in our dataset that should control for the vast majority of remaining unobserved factors that might bias the coefficient estimates in both of our models. That being said, as with any observational study, our causal identification claims are made cautiously. Nonetheless, we believe that the analysis employed in our article uncovers important relationships that are useful for smallholder agricultural policy in SSA.

Briefly, our results indicate that tenants in our sample were more likely to use inputs like inorganic fertilizer on plots they rented in and plots that they owner-cultivated themselves, compared to their landlords. However, tenants were less likely to make soil-fertility enhancing investments such as green compost on their rented-in plots compared to what their landlords did on their owner-operated plots. Tenants were also significantly less likely to invest in applying animal manure, green compost or minimum tillage on their rented-in plots compared to their 
owner-operated plots on average. Furthermore, it seems that the major factors affecting whether or not a landlord rented out a plot or cultivated it herself was whether or not there were observable assets such as fruit trees on the plot. Landlords were between $49-51 \%$ less likely to rent out a plot with a fruit tree on it, probably due to the income and nutrition that the fruit provided them.

\section{Land Rental Markets in Malawi}

Our data and analysis is set in Malawi. The country officially recognizes three types of land tenure regimes: i) the public tenure system which includes public lands, national parks etc; ii) the private tenure system which includes freehold, and leasehold land, where owners have titles and land can be bought, sold, and rented; iii) the customary tenure system. The customary tenure system is by far the largest in Malawi both in terms of landholding and number of people engaged (Lunduka, Holden, and Øygard 2009). Households who cultivate in the customary system have no formal title but have user rights that are granted by local chiefs. These land rights may be passed down from parents to children, but are ultimately controlled by the chief. Land renting is not explicitly allowed in the customary system, but land rental participation has been growing in Malawi, as mentioned earlier, under the de facto approval of local leaders.

Recent evidence suggests that land rental contracts in Malawi are almost entirely up-front cash-rent and short-term in nature, lasting one to two years on average (Ricker-Gilbert et al. 2019). In addition, tenants in Malawi have been found to be significantly wealthier than landlords along all dimensions of wealth other than land. This includes assets, savings, education and available labor (Chamberlin and Ricker-Gilbert 2016; Ricker-Gilbert et al. 2019). Both Chamberlin and Ricker-Gilbert (2016), and Ricker-Gilbert et al. (2019) found evidence to 
support the notion that landlords rented out land due to the need for immediate cash and/or because they lacked the necessary labor, rather than to earn can that could facilitate engagement in other productive non-farm activities.

\section{Land Tenure Security and Soil Fertility}

The literature clearly documents that land tenure insecurity is prevalent in many parts of Africa and in Malawi in particular. For example, in a survey of evidence across southern Africa, Mutangadura (2007) found that major causes of tenure insecurity included: loss of land rights for minority groups, unclear or overlapping land rights, overcrowding, and land alienation into leasehold, among other reasons. In particular, the author found that the transfer of land from customary to leasehold for investors during the 1980's and 1990's along with high and increasing population to land ratios were two of the major drivers of tenure insecurity in Malawi. A recent study in Malawi founds that tenure insecurity is widespread, with $22 \%$ of land users being concerned about losing their land (Deininger, Xia and Holden 2019). Peters and Kambewa (2007) found that impending land reform legislation that would formalize tenure rights in the customary sector in Malawi led to increased tenure insecurity and competition for land among smallholders.

Other studies from Malawi have found that individuals who lived in the home area of their spouses (e.g. a man residing in his wife's village) felt more tenure insecurity (Matchaya 2009; Lunduka, Holden and Øygard 2009). Both Martchaya (2009) and Lunduka, Holden and Øygard (2009) pointed out that particularly when a man resided in the wife's village and had no claim to the land other than through his wife, he was less likely to make longer-term investments 
in soil fertility. This was because he had no claim to the land if the marriage ended or his wife died.

Previous literature also supported the view that farmers have greater incentives to maintain soil fertility on owner-operated plots than on rented-in plots. This has been attributed to lack of commitment on the part of tenants due to the short-term nature of most land rental contracts (Jacoby and Mansuri 2008). Jacoby and Mansuri found that in Pakistan tenant farmers were less likely to invest in a non-contractible soil fertility investment (e.g. applying animal manure) than on owner-operated plots. This was even the case on plots under fixed-rent where the tenant maintained all output compared to share-cropped plots (ie: where the tenant shared output with the landlord). In the African context, Gavian and Fafchamps (1996; for Niger), Lovo (2016; for Malawi) and Muraoka, Jin and Jayne (2018; for Kenya) all found that rented-in plots were less likely to receive soil-conservation or fertility-enhancing investments compared with owner-cultivated plots.

The studies cited above provided important context that motivated the present study. We build upon this literature by using a matched sample of tenants and landlords to answer questions about input use and investments made on a tenant's rented-in plot, his or her owner-operated plot, and a landlord's owner-operated plot. We also seek to understand how objective and subjective measures of soil fertility and other investments influence a landlord's decision to rent out a particular plot, versus cultivate it for him or herself.

\section{Data}

Data used in this study came from four districts in Malawi collected between April and June 2016, which immediately followed the 2015/16 season. These districts were: Lilongwe, Salima 
and Nkhotakota in the Central region and Zomba in the Southern region. Nkhotakota and Salima were selected to represent rural areas, while Lilongwe and Zomba were selected to represent peri-urban areas. These specific districts were selected due to their high incidence of land rental market activity according to the 2009/10 nationally representative LSMS-IHS3 data. The total target sample size was 600, representing 150 farm households per sampled district. Since the IHS3 was only representative at the district level, after using those data to select districts, we contacted the District Agricultural Development Officer (DADO) as the entry point for the survey team. We used the DADOs' local knowledge to identify Extension Planning Areas (EPA) with high rental market activities within each district. Then within each of these EPAs, we randomly selected villages for our sample, choosing one village per EPA.

Once a village was selected, the field supervisors along with the local extension officer undertook a targeted household listing exercise. Smallholder farm households participating in land renting were identified through a Focus Group Discussion (FGD) with the Village Headman, lead farmers, and members of both Village Development Committees (VDC) and members of the Vulnerability Assessment Committee (VAC). These individuals were considered to be knowledgeable about the history of the village and related land issues. On average, the FGD comprised about 10 individuals of which 50 percent were women. Community-level issues regarding landownership, land availability and use, drivers of land renting, and prevailing farm gate prices of cash crops were discussed. The use of key informants to help identify respondents to answer questions about sensitive land-related issues has been used in many previous studies including Macours de Janvry and Sadoulet (2010), Macours (2014), Vranken et al. (2011), and Bardhan and Mookherjee (2010). 
At the end of each FGD, we then randomly sampled individual farming households from the village list of all households to serve as a sampling frame for our survey. ${ }^{5}$ The village leaders helped us to identify whether or not randomly selected households were tenants, landlords, or autarkic (neither renting in or renting out land). Each sampled landlord was matched to his or her tenant as pairs for the household interviews. Thus, if a tenant household was sampled, its corresponding landlord was automatically sampled for the interview and vice versa. ${ }^{6}$ Households were selected, with replacement until a sample size of 10 matched pairs was reached (i.e. 20 households). Furthermore, 10 autarkic households were randomly selected from the list as control households. Thus, a total of 30 households were sampled per village.

After cleaning the household data, our dataset consisted of 948 unique plots from 169 tenant and 169 landlords who formed rental pairs. Of these 948 plots, 347 were tenant's rented-in plots, 266 were tenant's owner-operated plots, and 335 were landlord's owner-operated plots. Appendix A presents the frequency on the number of plots controlled by tenants and landlords in the data.

\section{Soil data}

We took soil samples and GPS estimates of the area of surveyed plots according to the following criteria: the largest owner-operated plot cultivating maize and/or other annual crops for tenants and landlords. In addition, we took soil samples and GPS estimates of the area for the largest rented-in plot for each tenant and matched it to the landlord who had rented it out during that season.

Our survey team included soil technicians from the Lilongwe University of Agriculture and Natural Resources (LUANAR) soil lab. The technicians took two soil samples from each 
selected plot. Technicians took one sample from the topsoil $(0-20 \mathrm{~cm})$, while a second sample was collected for $20-40 \mathrm{~cm}$ below the surface (subsoil). Having a measure of quality for both the topsoil and subsoil gave us a more robust estimate of the soil health on the plot. ${ }^{7}$

After collection and labeling, the soil lab at LUANAR analyzed the soil samples for the following measures in both the topsoil and subsoil: nitrogen (\%), phosphorus (ppm), $\mathrm{pH}$, organic matter (\%), silt (\%), clay (\%), and sand (\%). These quantitative measures allowed us to measure soil quality broadly. In addition, we asked all households about their perceptions of the soil quality on their owned, rented-in, and rented-out plots. This enabled us to compare quantitative measurements of soil quality with farmers' assessments of soil quality. Furthermore, since we asked tenants and landlords about the soil quality on the rented plot that connected them, along with assessments of the soil quality on their respective owner-operated plots, we were able to observe how their perceptions about soil quality affected the land rental decision.

\section{Descriptive statistics}

Table 1 presents the descriptive statistics comparing means and standard deviations of key covariates used in the analysis for tenants, and their landlord pairs. It is clear from the table that the population of tenants was different from the population of landlords in our sample. The means of these variables were statistically different between tenants and landlords at the $1 \%$ level for all variables other than number of household members $(0.05<\mathrm{p}$-value $<0.10)$, if a member of the household belonged to a village savings and loan association $(0.01<\mathrm{p}-$ value $<0.05$ ), and walking distance to the nearest extension officer ( $\mathrm{p}$-value $>0.10$ ). Table 1 shows that tenants had on average 3.10 more years of education than landlords. Tenant households also had 0.47 more members on average than landlords, suggesting that tenant 
households had more available labor and also more mouths to feed. Tenant household heads were also statistically younger than landlords on average by more than seven years and less likely to be female headed, by 15 percentage points. Furthermore, tenants had a much higher average value of non-land assets at US $\$ 737$ compared to US $\$ 117$ for landlords, a difference of US $\$ 620$. In fact, the only asset that landlords seemed to have statistically more of than tenants was pre-rental landholding, with the average landlord holding 1.88 hectares, and the average landlord holding 0.83 hectares. These statistics are consistent with other studies from southern Africa which suggested that tenants on average have more non-land resources than landlords (Chamberlin and Ricker-Gilbert, 2016; Ricker-Gilbert et al., 2019). Our descriptive statistics provide prima facie evidence of tenants bringing education and assets into agriculture and using those resources to acquire land from less well-off landlord households.

[Table 1 here]

Table 2 compares the means in input usage and soil-fertility investments on tenants' rented-in plots (column 1), tenants' owner-cultivated plots (column 2), and landlords' ownercultivated plots (column 3). First, we found that tenants were statistically more likely to apply purchased inputs - particularly herbicide and inorganic fertilizer - than were landlords, on average. However, tenants did not apply these inputs at statistically different rates for their rented-in plots (column 1) versus their owner-cultivated plots (column 2). However, longer-term investments showed strong statistical differences between tenant's owner-operated and rented-in plots: rented-in plots received less animal manure, which is consistent with other empirical studies previously cited (e.g. Gavian and Fafchamps 1996; Jacoby and Mansuri 2008; Muraoka, Jin and Jayne 2018). While we do not know what investments landlords might have made on the rented-out plots had they not been rented out, it is nonetheless worth noting that in comparing the 
rented-in plots (operated by tenants) in column 1 with the landlord's owner-operated plots in column 3, we also found that there were statistically lower levels of longer-term investments on the rented-in plots managed by tenants for manure application, and green compost application, compared to the landlord's owner-operated plots.

[Table 2 here]

Considering the evidence from table 2 , that soil fertility investment seemed to be lower on rented-in plots than on owner-operated plots, table 3 provides some descriptive evidence on factors associated with which plots landlords decided to rent out vs. cultivate themselves. The table shows both objective measures and landlords' subjective perceptions of the soil quality characteristics of their plots. Interestingly, most quality measures between the landlords owned vs. rented-out plots were not statistically different. Landlords reported that both their owneroperated and rented-out plots are of good quality at similar rates (45\% and $47 \%$ respectively), and objective measures of soil acidity, organic matter, and phosphorous were not statistically different from one another. There was also no statistically significant difference in tenure insecurity on the plots that the average landlord rented-out vs cultivated themselves. However, rented-out plots were 17 percentage points less likely to have fruit trees planted on them (25\% of plots), compared to landlords' owner-operated plots (42\% of plots) (p-value $<0.01)$. These findings suggest that the soil quality of plots did not strongly influence whether or not they were rented out, although the presence of fruit trees - as income and sustenance generating assets was likely important.

[Table 3 here] 


\section{Input use and soil-fertility investments}

This article seeks to provide insights into the relationships between soil fertility, land rental markets and tenant and landlord interactions in Malawi. In this section we discuss how we test the key research questions presented in the article.

Question 1: How did input use and soil-fertility investment decisions differ across owned vs. rented plots operated by tenants and landlords?

First, we want to estimate how land rental markets affect input use and soil-fertility investments. The specific plot-level inputs that we model in the study are i) the number of times the plot was weeded, ii) if the farmer applied herbicides on the plot, iii) kilograms of inorganic fertilizer applied per hectare to the plot, and iv) if the farmer planted hybrid maize as the main crop on the plot. We would expect all of these to increase land productivity (yields) in the current year, but they all come with extra costs over traditional low-input farming systems. We briefly discuss these variables and the associated benefits and costs below.

\section{Number of times the plot was weeded}

The dependent variable "number of times the plot was weeded" is an important input on the plot because effective weed management is widely known to encourage crop growth and enhance the efficiency of nitrogen fertilizer (Snapp et al. 2014). At the same time weeding incurs labor costs which affect the optimal number of times a plot is weeded. For example, Kamanga et al. (2014) found that on average, when inorganic fertilizer was valued at highly subsidized prices through the Farm Input Support Program (FISP) in Malawi, the financial returns to labor were generally higher when farmers weed twice instead of once. Conversely when they valued fertilizer at commercial prices, they found that weeding once or twice did not generated returns to labor that exceeded the prevailing informal hired-in (ganyu) labor wage rate, of $\$ 0.53$ per day. The table in 
appendix B shows that in our data the median wage rate per day (4 hours of work) for ganyu labor during the 2015/16 season in Malawi was MWK 528, roughly equivalent to US $\$ 0.75$, and that $45 \%$ of the sample hired in some ganyu labor. In addition, $50 \%$ of the plots in our data were weeded once and $41 \%$ were weeded twice.

\section{Applied herbicides}

Herbicides are a technology to control weeds that can help farmers maintain yields and reduce labor costs, compared to weeding by hand in traditional smallholder cultivation systems. Furthermore, applying herbicides are an important input in minimum or zero tillage methods that are recommended as sustainable agricultural practices that farmers are often encouraged to adopt (Giller et al. 2009, discussed more below). The challenge for many smallholders is that applying herbicides means that they have to incur an extra input cost, and access to herbicides is severely limited in many parts of Malawi. Table 2 indicates that $21 \%$ of tenant's rented-in plots had herbicides applied to them, $24 \%$ of tenants' owner-cultivated plots had herbicides applied, while just $9 \%$ of landlords' owner-cultivated plots had herbicides applied. We did not attempt to value or create a price for herbicide due to the difficulty in standardizing the different types and quantities that farmers use. Regardless, the vast majority of smallholders do not apply herbicide regardless of ownership or cultivation status, and have to resort to using traditional hand weeding methods.

\section{Applied inorganic fertilizer}

Inorganic fertilizer is regarded as an important yield-increasing input in maize production in Malawi's nitrogen deficient soils (Maize Productivity Task Force, Action Group 1, 1999). The government of Malawi recommends that farmers apply inorganic fertilizer two times to their maize. The most common fertilizer blends in Malawi are NPK used as basil fertilizer applied 
during planting, and urea used as a top dressing to be applied once maize has sprouted. The table in appendix B indicates that $65 \%$ of our sample applied some amount of inorganic fertilizer during 2015/16. The median farmer in the sample who used inorganic fertilizer applied 100 kilograms, which is the recommended amount for one acre. The median commercial fertilizer price was MWK 360/kg roughly equivalent to USD \$0.50. This costs out to about US \$50 in total expenditure on inorganic fertilizer at commercial prices for people who purchase it in Malawi. This is a significant financial outlay for many smallholders.

\section{Planted hybrid maize}

Hybrid maize varieties have the potential to increase yields compared to traditional varieties. Hybrid varieties are shorter in stature than traditional varieties, and more of the plant's energy is transferred into the grain rather than to the stock of the plant. In addition, many of the hybrid varieties in Malawi are early maturing and drought resistant, allowing farmers to maintain yields in response to more sporadic rainfall and drought that has occurred in recent years, including during 2015/16 when our data were collected. Snapp et al. (2014) found that on average yields on hybrid maize plots in Malawi were $1,373 \mathrm{~kg} / \mathrm{ha}$, and $1,289 \mathrm{~kg} / \mathrm{ha}$ on plots with local maize varieties.

While there are yield benefits to hybrid seeds, there are additional costs and other potential drawbacks. First, hybrid seeds lose productivity if they are recycled and seed should be purchased every year, compared to traditional varieties that can be saved and re-used in multiple seasons. Second, Malawians tend to prefer the taste of traditional maize grain and traditional maize grain stores better than hybrid maize so the former often fetches a higher output price at market (Lunduka, Fisher and Snapp 2012). The table in appendix B indicates that $65 \%$ of households in our sample acquired hybrid maize seed, either through the subsidy program or 
purchased them on the commercial market. The table also shows that the median farmer who purchased commercial hybrid maize seed bought 10 kilograms, recommended for planting one acre. The median cost of commercial maize seed was MWK 700/kg roughly equal to US $\$ 1.00$.

The plot-level soil-fertility investments modeled in this article include: i) intercropping maize and legumes, ii) applying animal manure, iii) applying green compost, and iv) using minimum tillage methods. All of these practices can maintain and/or enhance soil fertility, leading to increased yields, profits and potentially better nutrition and food security. However, when implementing these practices, it takes time for the benefits to be translated into increased productivity. In addition, these practices impose additional costs in terms of labor and the need for complimentary input use (eg: herbicides to control weeds when using minimum tillage). We briefly discuss these soil fertility-enhancing investments below.

\section{Intercropped maize and legumes}

The general principle of intercropping in smallholder production systems involves planting maize with legumes, including common bean, groundnuts, pigeon pea or soybean. Intercropping benefits the soil because legumes fixate nitrogen in the soil, which offsets the nitrogen that maize takes out of it. Overtime this can reduce nitrogen depletion in the soil and reduces (but certainly does not eliminate) the need for inorganic fertilizer to be added to the soil. Bell et al. (2018) surveyed farmers in Malawi's Shire River valley and found that the main reasons they intercropped maize with legumes were to diversify their crop portfolio and reduce risk of maize crop failure, and to have more (nutritious) food to eat, and sell. The potential drawbacks to maize and legume intercropping are that maize production intensity and yields decline with lower planting densities and planting multiple crops together on a plot increases the amount of labor needed. The other challenge is that legume seeds have to be available when farmers need them at 
planting, which can be a problem for smallholders in Malawi. Kanyamuka et al. (2018) found that the main reason why adopters of the legume pigeon pea in Central Malawi stopped growing the crop was because they did not have consistent access to fresh seed.

\section{Applied animal manure}

Applying organic animal manure to plots is generally viewed as a sustainable agricultural intensification strategy that can be used as an agronomic compliment to inorganic fertilizers in smallholder production systems. Manure adds organic matter to the soil and improves its structure so that plants can use additional nitrogen from inorganic fertilizer more efficiently. However, it takes time for organic matter to accumulate in the soil and for soil structures to improve (Holden and Lunduka 2012). At the same time, organic manure is bulky and expensive to transport compared to inorganic fertilizer. Due to severe land constraints in Malawi, particularly in the southern part of the country, livestock density is low, making the benefits of organic manure difficult to access for limited resource smallholders.

\section{Applied green compost}

Green compost is created from crop residues, branches and other greenery, that smallholders apply to their fields to build up organic matter in their soils. Mulching green compost into the soil can improve its fertility over time, but like animal manure it takes several years for the benefits to be realized (Van Hulst and Posthumus 2016). In addition, crop residues have competing uses such as livestock feed, composting takes time to create, and it is labor intensive and bulky to transport and spread (Giller et al. 2009).

\section{Used minimum tillage}

Minimum or zero tillage systems where farmers avoid creating deep disturbances in the soil is often advanced as being an important component of sustainable agricultural intensification 
strategies (Giller et al. 2009). Leaving the soil untouched rather than creating ridges saves labor and increases fertility of the soil over time. It can also help prevent erosion and water logging caused by poorly constructed ridges. However, ridging is a traditional weed control strategy in smallholder production systems, and minimum tillage is not effective unless farmers have access to herbicides to control weeds (Ward et al. 2018). Given the resource constraints of many smallholder farmers and the lack of access to herbicides, it is difficult for many of them to practice minimum tillage methods.

\section{Empirical models}

Our first empirical model considers how these input use and soil-fertility enhancing investments differ among plots with three distinct types of ownership and cultivation status: 1) a tenant's rented-in plot that he or she cultivates, 2) the tenant's owner-operated plot, and 3) the landlord's owner-operated plot. We model these relationships on plot $i$ cultivated by household $j$ in rental pair $p$ as follows:

1) $X_{i j p}=\beta_{1} R_{i j p}+\beta_{2} T_{i j p}+\boldsymbol{H}_{j p} \boldsymbol{\beta}_{3}+\beta_{4} D_{i j p}+c_{p}+\epsilon_{i j p}$

Where $X$ represents an input, or soil-fertility investment decision on the plot, as discussed in the previous section. The variable $R$ is a binary indicator, equal to one if the plot belongs to plot status 1), namely that it is rented-in and thus cultivated by the tenant, while and $\beta_{1}$ represents the corresponding parameter to estimate. The variable $\mathrm{T}$ is also a binary indicator, equal to one if the plot belongs to plot status 2) the plot is owner-operated by the tenant. The corresponding parameter to estimate is $\beta_{2}$. The interpretation of the coefficient estimates $\hat{\beta}_{1}$ and $\hat{\beta}_{2}$ are important for answering how input use and investments differ across the three types of plot 
ownership and cultivation status. The sign and magnitude of $\hat{\beta}_{1}$ tests and compares how input use and investments differ on a tenant's rented-in plot (plot status 1) compared to his or her landlord's owner-operated plot (plot status 3). The sign and magnitude of $\hat{\beta}_{2}$ tests and compares how input use and investments differ on a tenant's owner-operated plot and his or her landlord's owner-operated plot (status 2 vs status 3). We can compare the differences between a tenant's rented-in plot and his or her owner-operated plot (status 1 vs status 2) with an F-test of equality between $\hat{\beta}_{1}$ and $\hat{\beta}_{2}{ }^{8}$

Given the short-term nature of rental contracts in Malawi, we might expect input use to be higher among tenants and on rented-in plots compared to landlord's owner-operated plots because the tenant operators seek short-term yield gains on the rented land. As mentioned, previous literature from Malawi indicated that tenants were also likely to have more savings and assets than landlords so were likely more able to purchase fertilizer, seed, pesticides and other inputs. At the same time, we hypothesize that soil fertility investments might be lower on rentedin plots than they are on owner-cultivated plots, either managed by tenants or landlords. This is because of the longer-time horizon for these benefits to materialize and the likely shorter-term nature of the rental arrangements, as seen in previous literature (Gavian and Fafcahmps 1996; Muraoka, Jin and Jayne 2018). The comparison of the coefficient estimates $\hat{\beta}_{1}$ and $\hat{\beta}_{2}$ to each other and to the control (landlord's owner operated plots) gives a more complete picture of decisions made by land owners and land operators, that has yet to be analyzed before now to our knowledge.

Equation 1 also includes a set of household-level controls that are denoted by the vector H. These include pre-rental landholding, which includes all land that is cultivated by the household (excluding rented-in land) in addition to land that will be rented out, and land that is 
fallowed, used as a woodlot or in pasture. ${ }^{9}$ The vector $\mathbf{H}$ also includes number of household members, a proxy for available family labor along with number of mouths to feed. In addition, gender of the household head, age of the household head, household savings, value of household assets, number of plots cultivated by the household, if someone the household is a member of a village savings and loan association, and walking distance to nearest extension office are all included as control variables in $\mathbf{H}$. The corresponding parameter vector in equation 1 is denoted by $\boldsymbol{\beta}_{3}$. Additionally, we add one other plot-level variable, distance to the plot from the operator's home in walking minutes. This factor is denoted by $\mathrm{D}$, with corresponding parameter $\beta_{4}$.

The rental pair-specific unobserved FE that could influence the rental decision is denoted by $\mathrm{c}$ in equation 1 . This variable captures unobserved differences across tenant-landlord pairs that could influence unobservable factors such as ability, motivation and which plots have been rented in or out. Such unobservable variables include social and power dynamics and social connections within the rental partner pair (Bellemare 2012; Deininger, Ali and Alemu 2013). We deal with this potential source of endogeneity by estimating equation 1 using rental-pair FE. Rental-pair FE controls for unobserved heterogeneity within the tenant-landlord pair, but as Bellemare (2012) pointed out, it does not control for selection into rental status as a tenant or landlord. Rather the results of this analysis are consistent for measuring impacts conditional on being engaged in the land rental market, either as a tenant or a landlord. As such, the results are not fully generalizable to the broader population of smallholders in Malawi, but are relevant for people who are already either tenants or landlords. We argue that this is the primary population of interest in the present study because some people in the smallholder population are unlikely to ever engage in land renting. Ultimately, we recognize that even with a rich set of controls and 
pair-specific FE, we cannot assume full causality of our results. This is the case with any study using observational data, but we believe that the analysis employed in our article uncovers important relationships that are useful for smallholder agricultural policy in SSA.

The plot and household specific error term is represented by $\epsilon$, which is assumed to be uncorrelated with the observable covariates in equation 1 after controlling for rental-pair FE.

Question 2: How do subjective and objective measures of soil fertility, along with investments affect a landlord's rental decision?

In order to answer the question above, we explicitly model the landlord household j's rental decision for plot $\mathrm{i}$ at the beginning of the agricultural season as a function of the following:

2) $Y_{i j}=\alpha_{1} S_{i j}+\alpha_{2} I_{i j}+\boldsymbol{Q}_{i j} \boldsymbol{\alpha}_{3}+\alpha_{4} C_{i j}+a_{j}+v_{i j}$

where $\mathrm{Y}$ is equal to one if the landlord chooses to rent out the plot, and zero if she chooses to cultivate it herself. The first key covariate to consider in our analysis is denoted by $\mathrm{S}$, which is equal to one if the household believes that the soil fertility on plot $\mathrm{i}$ is of good or very good quality, and equal to zero otherwise. The corresponding parameter to estimate is denoted by $\alpha_{1}$. The sign and statistical significance tests whether or not a landlord rents-out the plot that she perceives to be of better or worse soil fertility.

The variable I in equation 2 represents the binary indicator for whether or not there is a fruit tree on the plot. This variable is meant to proxy for the investment decisions made in previous years on the plot that may affect household income and/or the plot's soil fertility in the future. The fruit that the trees bear serve as a resource that the household can consume or sell, with $\alpha_{2}$ as the corresponding parameter. This variable tests whether or not landlords are more or 
less likely to rent out the plots that have received an investment previously. The table in appendix B shows that 58 percent of households have ever purchased a fruit tree, and conditional on purchasing a tree, 5 was the median number of trees purchased while 6 was the mean number purchased. The median fruit tree value was MWK 2,000 per tree (US \$ 2.85), while the mean was MWK 3,779 (US \$ 5.40).

One may wonder if a fruit tree on a rented plot could have been planted by a tenant in the past rather than by the landlord. There is no way to rule this out for certain. However, it seems unlikely because most of the renting in this context is very short term, as evidenced in the previous literature (Lunduka, Holden, and Øygard 2009; Chamberlin and Ricker-Gilbert 2016; Ricker-Gilbert et al. 2019). Furthermore, appendix C shows that that $78 \%$ of rented plots in our data were rented out for 2 years or less over the past 5 years. Since fruit trees are a relatively fixed investment, this suggests that any trees planted on rented out plots were likely planted by the owning landlord sometime in the past. ${ }^{10}$

The vector Q represents the unobservable, quantitative soil fertility measures on the plot's top-soil $(0-20 \mathrm{~cm})$. These include the level of phosphorus measured in parts per million (ppm), level of organic matter in \%, and if the soil is acidic with $\mathrm{pH}$ below 5.2. The corresponding parameter vector is $\alpha_{3}$. These are important measures for testing the extent to which landlords are aware of objective soil fertility on the plot and how this may affect his or her rental decision.

We also include the variable $\mathrm{C}$ in equation 2 to provide us with a measure of how tenure insecurity affects the decision to rent. The variable is equal to one if the landlord believed that someone was likely to make a tenure claim against his or her plot. The corresponding parameter 
is $\alpha_{4}$. The error term in equation 2 has two components. First, the landlord-specific unobserved effect (FE) is denoted by a, while $\boldsymbol{v}$ denotes the household and plot specific error.

The identification strategy used to deal with correlation between the error term and observed covariates in equation 2 is similar to equation 1 , as we are primarily concerned with omitted variable bias. We deal with this first by adding the plot-level controls as mentioned above, thus removing them as omitted variables in the model.

Second, since we have multiple plots per household, we are able to use landlord FE to remove the individual landlord-specific error term, a, from equation 1. Doing so removes demographic characteristics of the landlord such as age, education and gender, as those are constant within the individual landlord. The plot specific error, $v$, is assumed to be uncorrelated with the covariates in equation 2, conditional on the observed covariates and $a$.

\section{Estimator choice}

Most of the dependent variables in the models presented in this article are binary responses, taking on a zero or one value (the only exceptions are number of times the plot was weeded and kilograms of inorganic fertilizer applied per hectare). We estimate these linearly using rental pair FE as discussed earlier. As such, the binary dependent variables in these equations are estimated as a linear probability model (LPM). LPM has the advantage over a non-linear estimator such as probit, because it provides easy to interpret coefficients. LPM also allows us to use tenant-landlord pair FE, which would be biased in probit estimation, due to the incidental parameters problem (Wooldridge, 2010). We cluster the standard errors of our estimates at the rental pair level to deal with concerns about heteroscedasticity and serial correlation when using the LPM. 


\section{Results}

Table 4 presents the results for equation 1 that estimates the factors affecting plot-level input use among i) a tenant's rented-in plot(s) $\left(\hat{\beta}_{1}\right)$, ii) a tenant's owner-operated plot(s) $\left(\hat{\beta}_{2}\right)$ and iii) his or her landlord's owner-operated plot(s) as the base for comparison. These models were estimated linearly via rental-pair FE to control for unobservable factors in the relationship between tenants and landlord pairs. We see that there was no statistical difference among ownership status and management of the plot for number of times the plot was weeded in column 1. However, in column 2 , tenants were 8 percentage points more likely to apply herbicide on their ownercultivated plot than were landlords on their owner-cultivated plot (p-value<0.10). This was nearly double the 9 percent of landlords who applied herbicides to their owner-cultivated plots (as seen in table 2). The same relationship held in column 3 for kilograms of inorganic fertilizer applied per hectare. Tenants applied 78 kilograms per hectare more fertilizer on average on plots that they owner-operated, compared to their landlords' owner-operated plots (p-value $<0.01$ ). This was a substantial $51 \%$ increase over the mean fertilizer application on a landlord's plot of 152 kilograms per hectare (as seen in table 2). Tenants also applied nearly 61 kilograms more inorganic fertilizer per hectare on rented-in plots than their landlords did on their owner-operated plots on average ( $\mathrm{p}$-value $<0.05$ ). This was equivalent to a $40 \%$ increase in fertilizer application over their landlord's owner-operated plot(s) on average. However, we did not observe statistically significant differences between tenant-operated plots (both rented-in or owneroperated), and landlords' owner-operated plots in terms of number of times the plot was weeded or whether hybrid maize was the main crop.

To evaluate differences between input usage by tenants on their owned versus rented-in plots, we computed F-tests comparing $\hat{\beta}_{1}$ and $\hat{\beta}_{2}$ for each model. The only significant difference 
was in column 4 (hybrid maize usage): tenants were 11 percentage points more likely to plant hybrid maize on their owned-plot rather than their rented-in plots on average (appendix D shows the main crops that were planted on plots based on ownership and cultivation status). One revealing insight from appendix D is that tenants grew groundnuts on nearly $30 \%$ of rented-in plots, compared to groundnuts being grown on only $17 \%$ of tenants' owner-cultivated plots and $19 \%$ of landlords' plots. This may suggest that tenants focused on planting maize as a food security crop on their owned plots but were more likely to use the rented-in plots to expand their area cultivated into cash crops like groundnuts.

Table 5 presents the results for factors affecting plot-level soil fertility investments among a tenant's rented-in $\operatorname{plot}(\mathrm{s})\left(\widehat{\boldsymbol{\beta}}_{\mathbf{1}}\right)$ a tenant's owner-operated $\operatorname{plot}(\mathrm{s})\left(\widehat{\boldsymbol{\beta}}_{\mathbf{2}}\right)$ and his or her landlord's owner-operated plot(s) (control). As in table 4, the models in table 5 were estimated linearly via rental-pair FE. For the most part, there are no statistically significant differences in the probability of longer-term investments for tenants' rented-in and his or her owner-operated plots compared with his or her landlords' owner-cultivated plots. The only significant exception is that, on average, rented-in plots were 7 percentage points less likely to receive green compost by a tenant operator, as compared with a landlord's green compost usage on their owneroperated fields. This result makes sense given the time, labor and crop residues required to generate green compost: because crop residues have alternative uses and land renting is shortterm, tenants may have greater incentives to apply such resources on their own plots where lagged benefits will not be lost.

The comparisons of tenant investments on rented-in vs. his or her owner-cultivated plots were more striking $\left(\hat{\beta}_{1}=\hat{\beta}_{2}\right)$. The F-tests at the bottom of columns 2,3 and 4 indicated that tenants were much less likely to use animal manure, green compost and minimum tillage 
practices on their rented-in plots than they were on their owner-operated plots by 11,5 and 5 percentage points on average, respectively. These changes were very different than the means on tenant's owner cultivated plots representing a $42 \%$ decline in the probability of applying animal manure, a $45 \%$ decline in the probability of using green compost, and a $35 \%$ decline in the probability of using green compost, albeit from a relatively low base (as seen in table 2).

Regardless, these results were all in line with our expectations, and consistent with the previous literature about the inability of tenants to capture lagged returns under short-term tenancy arrangements (Gavian and Fafchamps 1996; Jacoby and Mansuri 2008; Lovo 2016; Muraoka, Jin and Jayne 2018). As mentioned earlier, these soil fertility-enhancing investments take time to generate returns. Furthermore, organic animal manure requires access to animals and labor, green compost requires access to labor and crop residues which have alternative uses, while minimum tillage is enabled by herbicide application which is an added input cost and access is very limited for many smallholders in Malawi. Obviously, if tenants have to make decisions about where to incur these costs to obtain soil fertility benefits from these investments, they generally choose to do so on their own plots rather than the rented ones. As such, it would seem that tenants in our sample were not investing in their rented-in plots and may in fact have been mining the soil nutrients on these plots. We also know that tenants in or sample were wealthier than landlords on average in terms of wealth, savings and education. These findings raise the question that we address in table 6: what factors affected the landlord's choice of which plot to rent out and which to retain for her own cultivation?

Table 6 presents the results of the model that estimated factors associated with which plot(s) a landlord decided to rent out, estimated via landlord-FE LPM. Columns 1-4 show the base model presented in equation 2 with alternative sets of explanatory factors in each column, 
while the specification in column 5 includes all factors simultaneously. We see from these results that a landlord's perception of the soil quality on the plot did not significantly affect his or her decision to rent-out the plot. However, in columns 3 and 5, we see that plots with fruit trees on them were 49-51 percentage points less likely to be rented out, on average ( $\mathrm{p}$-value $<0.01$ ). This suggests that landlords viewed fruit trees as important productive assets, and were reluctant to part with plots that had such trees. ${ }^{11} \mathrm{We}$ also found evidence in column 2 that plots with higher soil organic matter were less likely to be rented out on average, with results approaching statistical significance $(0.10<\mathrm{p}$-value $<0.11)$.

Interestingly, we found marginally significant evidence that landlords who felt insecure about their tenure claim to a plot were between $29-33$ percentage points more likely to rent it out on average than those who did not $(0.05<\mathrm{p}$-value $<0.10$ in column 5$)$. One possible interpretation of this result is that if landlords were labor or capital constrained, and unable to farm all the land in their possession, they may have perceived a greater risk of appropriation/reallocation from leaving the land idle rather than letting a tenant cultivate it. ${ }^{12}$ Another possibility is that, facing some uncertainty about eventual reallocation by traditional authorities, a landlord would rather earn income on a risky asset while such an opportunity remains available.

We investigated this finding further by estimating a plot-level model of factors affecting the landlord's perception of insecurity across his or her plots. The model regressed a binary variable for insecurity (i.e. the expressed concern by the respondent that someone will challenge his or her tenure claim) on i) distance from the home to the plot, ii) his or her subjective views on soil quality and soil color, iii) if the plot was obtained from the local chief (as opposed to inheriting it directly from a parent, or purchasing it with title), and iv) if the male in the 
household was the main operator of the plot. The estimation results of this model are shown in appendix E. They indicate that obtaining the plot from a chief had a marginally significant effect on landlord's perception of insecurity about the plot, at the $10 \%$ level of significance. In fact, the coefficient estimate suggests that the average household who obtained the plot from the chief was between $29-31 \%$ more likely to feel insecure about their claim to it. This finding suggests that ceteris paribus when smallholders obtain plots directly from chiefs, rather than through inheritance claims or direct purchases, they are more likely to perceive a risk of having that land taken away. This may reflect that land obtained directly from chiefs was probably acquired more recently and could be more easily taken away, relative to land that has been inherited and controlled by the farmer's family for multiple generations.

\section{Robustness checks}

"For each of the model specification results reported in Tables 4-6, we also generated a number of alternative specifications, with the objective of evaluating the robustness of our results. In appendices $\mathrm{F}$ and $\mathrm{G}$ we ran parsimonious models with and without pair-wise $\mathrm{FE}$, as well as a specification with a full set of covariates but without the pair-wise FE. In appendix H we show specifications that were analogous to the main landlord results in table 6 , but without landlord FE. Across the specifications in the appendices, the signs were all the same and coefficients were generally of similar magnitude to our main results. Fewer coefficients were statistically significant in tables 4-6 than they were in the appendices, suggesting that the FE estimators with additional controls provided the most conservative estimates, justifying why we used them in our 
main analysis. Overall our analytical conclusions did not change substantively when we added these robustness checks.

\section{Discussion}

Our findings are relevant to the contemporary policy debate on how best to facilitate sustainable intensification in SSA (Sanchez 2002; van Ittersum et al. 2016; Holden 2018; Jayne et al. 2019). Results suggest that the answer to this question is not simply a technological one, but one that addresses how the incentives for soil fertility investments are conditioned by land institutions, including farmland rental markets. Population is growing rapidly in the region against a relatively fixed land base, and land rental markets are responding. Such markets are the most feasible way for land resources to be quickly and efficiently reallocated to those who wish to expand their cultivated area and to invest management and financial resources in the sector. However, our results suggest that, in the absence of other interventions, the de facto expansion of rental markets in SSA will likely incur negative impacts on soil fertility, even if sectoral productivity increases in the shorter term.

This has implications for the long-run fertility and health of African soil, which are already in crisis (Sanchez 2002; Drechsel et al. 2001). The answer, surely, is not to restrict rental market development, which does appear to bring about important positive productivity gains (Holden et al. 2009; Jin and Jayne 2013; Chamberlin and Ricker-Gilbert 2016), but rather to facilitate tenure security for landlords which may facilitate longer-term rental arrangements which create greater incentives for fertility investments by tenants. In addition, it may be possible to design contracts that incentivize longer-term investments directly. For example, in a study of land rental markets in the Czech Republic, Sklenicka et al. (2015) found that while owner-operators were more likely than tenants to invest in soil erosion control, tenants could be 
incentivized through subsidies to adopt soil erosion control if an effective verification and payment system was put in place. This could perhaps be feasible in our context as we found evidence that tenants were more likely to invest in the soil fertility of their owner-operated plots, than their rented plots. This suggests that they know the benefits of soil fertility enhancing measures but are not incentivized to care about them on their rented-in plots. Additional research may clarify the responsiveness of rental arrangements (and investments made within such rental contexts) to different levels of tenure security and contract choices.

Nonetheless, on the basis of our results, we consider some simple benefit-cost calculations on the basis of expected input intensification by landlords in the short-run vs the costs of decreased soil fertility in the longer-run. Column 3 in table 4 indicated that on average moving land from landlords to tenants added an extra 61 kilograms per hectare to Malawi's soil. If we assume a maize to fertilizer response rate of 4:1 (Jayne and Rashid 2013), we obtain a return of an extra 244 kilograms of maize per hectare compared to land managed by landlords. The nationally representative 4th Integrated Household Survey of Malawi indicates that $13 \%$ of plots and 385,000 hectares of land were rented during the 2015/16 season. This suggests that an extra 23,500 tons of fertilizer was added to Malawi's soils through land renting, leading to an additional 94,000 tons of maize produced (assuming a 4:1 fertilizer to maize response ratio). If we assume a maize grain price at harvest of $\$ 250$ per ton, then the total revenue from the additional production would be US $\$ 23.5$ million in 2015/16.

Next the benefits of increased fertilizer and maize production need to be assessed against the cost of fertilizer and labor requirements of applying more fertilizer. In this study we found the average hired labor price was about US $\$ 1.40$ per day, and we assumed it takes an extra day to apply 61 additional kilograms of fertilizer per hectare. We also found fertilizer to be priced at 
$\$ 0.71$ per kilogram on average in our data. As such the total cost of this increased production would be $\$ 0.71 * 61 \mathrm{~kg}+\$ 1.40=\$ 45$ per hectare $* 385,000$ rented hectares for a total cost of $\$ 17.33$ million in aggregate. This suggests that renting land generated a current year benefit/cost ratio of 1.36 (i.e. benefits of $\$ 23.5$ million / costs of $\$ 17.33$ million) on average in $2015 / 16$. The cost of renting land is considered to be a transfer from tenants to landlords, and the net benefits need to be weighed against the potential longer-term soil fertility decline from renting land, as evidenced by tenants being seven percentage points less likely to apply green compost to rentedin plots than their landlords on average (table 5). More detailed estimates of the longer-term costs of soil fertility declines under reduced soil fertility investments is beyond the scope of our analysis, but certainly merits further study.

\section{Conclusions}

This study used a unique data set on matched-tenant landlord pairs from four districts in Malawi to compare input use and soil fertility investment decisions among tenants' rented-in plots, tenants' owner-operated plots, and the owner-operated plots of their landlords. To our knowledge this is the first study to do so, giving us greater insights into how both tenant and landlord production decisions are affected by rental market participation. The latter has been particularly weak in the empirical literature, due to low rates of observation of landlords relative to tenants in survey data (Chamberlin and Ricker-Gilbert 2016; Deininger et al. 2017). We also investigated the factors which affect landlords' decisions on which plots to rent out and which to cultivate herself at the start of the season. Since we have multiple plots per household and per rental pair, we use rental-pair and household fixed effects to identify our results. 
Our findings were consistent with earlier studies from Malawi, which indicated that tenants were generally wealthier than landlords on all dimensions besides pre-rental landholding, i.e. assets, savings and education (Chamberlin and Ricker-Gilbert 2016; Ricker-Gilbert et al. 2019). Tenants in our sample were more likely to apply annual inputs like herbicide and inorganic fertilizer on their owner-operated plots compared to landlords. However, tenants were less likely to make soil-fertility enhancing investments such as applying green compost on their rented-in plots compared to their landlords. In addition, tenants were less likely to apply organic manure, green compost or minimum tillage on rented-in plots than they were on their ownercultivated plots. Previous studies have also found that tenants were more likely to make longerterm soil conservation/enhancement investments on owner-operated plots relative to rented-in plots (e.g. Gavian and Fafchamps 1996; Jacoby and Mansuri 2008; Lovo 2016; Muraoka, Jin and Jayne 2018). Our results add to this literature by comparing a variety of soil fertility investments on tenants' rented-in plots, their owner-operated plots, and their landlord's owner-operated plots, using our matched sample. Furthermore, it seemed that the major factor affecting whether or not a landlord rented out a plot was the presence of readily observable endowments, as landlords were between 49-51 percentage points less likely to rent out a plot with fruit trees on it.

Our overarching interest has been to generate policy-relevant insights about the impacts of rental market participation on soil fertility investments through a more comprehensive assessment of both landlord and tenant sides of the market than has been done to date. Our comparison of rented and unrented plots operated by tenants is consistent with earlier studies which suggest that soil fertility investments are lower in rented-in plots compared with tenant's owner-operated plots. However, our comparison of rented out versus landlord operated plots which has largely been unexamined in prior literature - offers tentative evidence of differences 
in soil fertility management, primarily via lower use of green compost, but not through the other investments evaluated. More empirical work, covering larger geographical diversity, will help to clarify the net soil fertility management implications of expanding farmland rental markets in the longer-term. The short-term gains from higher expected fertilizer investments by wealthier tenant farmers appear to be important, but figuring out how to incentivize greater fertility investments in farming systems which are increasingly defined by rental transactions is essential for long term sustainable productivity increases in the region.

\section{Acknowledgements}

The authors acknowledge funding for this research from the Bill and Melinda Gates foundation under the Guiding Investments in Sustainable Agricultural Intensification in Africa project led by Michigan State University. We are thankful to participants at the 2018 Agricultural and Applied Economics Association Annual Meeting, along with the Editor Daniel Phaneuf and two anonymous referees for helpful feedback. All remaining errors are our own.

The authors would like to dedicate this paper to the memory of Dr. Rodney Lunduka, who assisted with data collection for this research. He was a longstanding collaborator and valued colleague and friend.

\section{References}

Bardhan, P., and Mookherjee, D., 2010. Determinants of redistributive politics: an empirical analysis of land reforms in West Bengal, India. American Economic Review. 100(4), 1572-1600.

Bell, A.R., J.Z. Cheek, F. Mataya, and P.S. Ward. 2018. "Do As They Did: Peer Effects Explain Adoption of Conservation Agriculture in Malawi." Water 10(51) doi:10.3390/w10010051

Bellemare, M. 2012. "Insecure Land Rights and Share Tenancy: Evidence from Madagascar." Land Economics 88(1):155-180.

Berazneva, J., L. McBride, M. Sheahan, and D. Guerena. 2018. "Empirical Assessment of Subjective and Objective Soil Fertility Metrics in East Africa: Implications for Researchers and Policy Makers." World Development. 105:367-382.

Carletto, C., S. Savastano, and Z. Alberto. 2013 "Fact or Artifact: The Impact of Measurement Errors on the Farm Size Productivity Relationship." Journal of Development Economics 103: 254-261. 
Chamberlin, J, and J. Ricker-Gilbert. 2016. "Participation in Rural Land Rental Markets in subSaharan Africa: Who benefits and by how much? Evidence from Malawi and Zambia." American Journal of Agricultural Economics 98(5):1507-1528

Deininger, K., D. A. Ali, and T. Alemu. 2013. "Productivity effects of land rental market operation in Ethiopia: Evidence from matched landlord-tenant sample." Applied Economics 45(25): 3531-3551.

Deininger, K., S. Savastano, F. Xia. 2017. “Smallholders' land access in sub-Saharan Africa: A new landscape." Food Policy 67:78-92.

Deininger, K., F. Xia, and S. Holden. 2019. "Gendered Incidence and Impacts of Tenure Insecurity on Agricultural Performance in Malawi's Customary Tenure System.” Journal of Development Studies 55(4):597-619.

Drechsel, P., Gyiele, L., Kunze, D. and Cofie, O., 2001. Population density, soil nutrient depletion, and economic growth in sub-Saharan Africa. Ecological Economics, 38(2), pp.251-258.

Gavian, S. and M. Fafchamps. 1996. "Land Tenure and Allocative Efficiency in Niger." American Journal of Agricultural Economics 78:460-471.

Giller, K.E., Witter, E., Corbeels, and M., Tittonell, P., 2009. "Conservation agriculture and smallholder farming in Africa: the heretics' view." Field Crops Research. 114 (1), 23-34.

Ghebru, H. H., \& Holden, S. T. 2014. Reverse-share-tenancy and agricultural efficiency: Farmlevel evidence from Ethiopia. Journal of African Economies 24(1), 148-171.

Gourlay, S. E. Aynekulu, C. Carletto, and K. Shepard. 2017. "Spectral Soil Analysis \& Household Surveys. A Guidebook for Integration.” The World Bank. Washington DC.

Holden, S.T., K. Otsuka, and F.M. Place, eds. 2009. The Emergence of Land Markets in Africa: Impacts on Poverty, Equity and Efficiency. Washington D.C.: Resources for the Future Press.

Holden, S.T. and R. Lunduka. 2012. "Do fertilizer subsidies crowd out organic manures? The case of Malawi." Agricultural Economics 43(3):303-314

Holden, S.T. and Ghebru, H. 2016. Land rental market legal restrictions in Northern Ethiopia. Land Use Policy, 55, pp.212-221.

Holden, S.T., Deininger, K. and Ghebru, H., 2011. Tenure insecurity, gender, low-cost land certification and land rental market participation in Ethiopia. The Journal of Development Studies, 47(1), pp.31-47. 
Holden, S. T., Deininger, K. and Ghebru, H. 2008. "Impact of land certification on land-related conflicts”. Working Paper, Norwegian University of Life Sciences, Ås.

Jacoby, H.G., and G. Mansuri. 2008. "Land Tenancy and Non-Contractible Investment in Rural Pakistan." Review of Economic Studies 78:763-788.

Johnston, B.F., and Kilby, P., 1975. Agriculture and structural transformation: Economic strategies in late developing countries. New York: Oxford University Press.

Kamanga, B.C.G., S.R. Waddington, A.M. Whitbread, C.J.M Almekinders, and K.E. Giller. 2014. "Improving the efficiency of the use of small amounts of nitrogen and phosphorus fertilizer on smallholder maize in Central Malawi." Experimental Agriculture. 50 (2): 229-249.

Lovo, S. 2016. "Tenure Insecurity and Investment in Soil Conservation. Evidence from Malawi." World Development 78:219-229.

Lunduka, R., S. T. Holden and R. Øygard. 2009. "Land Rental Market Participation and Tenure Security in Malawi." Chapter 6 in: Holden, S. T., K. Otsuka and F. M. Place, eds. The Emergence of Land Markets in Africa: Impacts on Poverty, Equity and Efficiency, Resources for the Future Press, Washington, D.C., pp. 112-130.

Lunduka, R., Fisher, M., Snapp, S., 2012. “Could farmer interest in diversity of seed attributes explain adoption plateaus for modern varieties in Malawi?" Food Policy 37 (5): 504-510.

Macours, K., de Janvry, A., and Sadoulet, E., 2010. Insecurity of property rights and social matching in the tenancy market. European Economic Review. 54(7), 880-899.

Macours, K., 2014. Ethnic divisions, contract choice, and search costs in the Guatemalan land rental market. Journal of Comparative Economics. 42, 1-18.

Maize Productivity Task Force, Action Group I. 1999. "Validating and strengthening the areaspecific fertilizer recommendations for hybrid maize grown by Malawian smallholders: A research report of the results of the nationwide 1997/98 Maize Fertilizer Recommendations Demonstration." Lilongwe: Ministry of Agriculture and Irrigation Matchaya, G. 2009. "Land Ownership Security in Malawi." African Journal of Agricultural Research 4(1):1-13.

Miller, D.C., Muñoz-Mora, J.C. and Christiaensen, L., 2017. Prevalence, economic contribution, and determinants of trees on farms across Sub-Saharan Africa. Forest Policy and Economics, 84, pp.47-61.

Muraoka, R., S. Jin, and T.S. Jayne. 2018 "Land access, land rental and food security: Evidence from Kenya." Land Use Policy 70: 611-22. 
Mutangadura, G. 2007. "The Incidence of Land Tenure Insecurity in Southern Africa: Policy Implications for Sustainable Development," Natural Resource Forum 31:176-187.

Peters, P.E., and D. Kambewa. 2007. "Whose Security? Deepening Social Conflict Over 'Customary' Land in the Shadow of Land Tenure Reform in Malawi." Journal of Modern African Studies 45(3):447-472.

Ricker-Gilbert, J. C. Jumbe, J. Kanyamuka, J. Chamberlin, R. Lunduka and S. Kaiyatsa. 2019. "How do Informal Farmland Rental Markets Affect Smallholders' Well-being? Evidence from a Matched Tenant-Landlord Survey in Malawi." Agricultural Economics 50(5):595-613.

Sanchez, P.A. 2002 “Soil Fertility and Hunger in Africa.” Science 295(5562):2019-2020.

Sklenicka, P., K.J. Molnarova, M. Salek, P. Simova, J. Vlasak, P. Sekac, V. Janovska. 2015. "Owner or Tenant: Who Adopts Better Soil Conservation Practices." Land Use Policy 47:253-261.

Snapp, S. T.S. Jayne, W. Mhango, T. Benson, and J. Ricker-Gilbert. 2014. "Maize Yield Response to Nitrogen in Malawi's Smallholder Production Systems.” Malawi Strategy Support Program Working Paper \#9. Lilongwe, Malawi.

Van Hulst, F.J., and H. Posthumus. 2016. "Understanding (non-) adoption of Conservation Agriculture in Kenya using the Reasoned Action Approach." Land Use Policy 56:303314.

van Ittersum, M.K., L.G.J. van Bussel, J. Wolf, P. Grassini, J. van Wart, N. Guilpart, L. Claessens, H. de Groot, K. Wiebe, D. Mason-D’Croz, H. Yang, H. Boogaard, P. A. J. van Oort, M.P. van Loon, K. Saito, O. Adimo, S. Adjei-Nsiah, A. Agali, A. Bala, R. Chikowo, K. Kaizzi, M . Kouressy, J.H.J.R. Makoi, K. Ouattara, K. Tesfaye, and K.G. Cassman. 2016. "Can sub-Saharan Africa Feed Itself?" Proceedings of the National Academy of Sciences of the United States of America. 113(52):14964-14969.

Vranken, L., Macours, K., Nivelin, N., and Swinnen, J., 2011. Property rights imperfections, asset allocations and Welfare: Co-ownership in Bulgaria. Journal of Comparative Economics. 39, 159-175.

Ward, P.S, A.R. Bell, K. Droppelmann, and T.G. Benton. 2018. "Early adoption of conservation agriculture practices: Understanding partial compliance in programs with multiple adoption decisions." Land Use Policy 70:27-37.

Wooldridge, J. M. 2010. Econometric Analysis of Cross Section and Panel Data, 2nd Edition, MIT Press, Cambridge, MA. 
Table 1. Descriptive comparisons between tenant and landlords

\begin{tabular}{|l|c|c|c|c|c|}
\hline & \multicolumn{2}{|c|}{ Tenant } & \multicolumn{2}{c|}{ Landlord } & $\begin{array}{c}\text { Difference: } \\
\text { Tenant }- \\
\text { Landlord }\end{array}$ \\
\hline $\begin{array}{l}\text { Education of household head in years of } \\
\text { schooling }\end{array}$ & Mean & SD & Mean & SD & $3.10^{* * *}$ \\
\hline Pre-rental landholding in hectares & & 4.36 & 4.65 & 3.68 & \\
\hline Number of household members & 0.83 & 1.07 & 1.88 & 1.56 & $-1.05^{* * *}$ \\
\hline$=1$ if household head is female & 5.47 & 2.38 & 5.00 & 2.18 & $0.47^{*}$ \\
\hline Age of household head in years & $0.11^{* * *}$ & 0.31 & 0.26 & 0.44 & $-0.15^{* * *}$ \\
\hline Savings in USD & $40.50^{* * *}$ & 12.18 & 47.55 & 16.17 & $-7.05^{* * *}$ \\
\hline Value of assets in USD & $\$ 80^{* * *}$ & $\$ 265$ & $\$ 10$ & $\$ 32$ & $\$ 70^{* * *}$ \\
\hline Number of plots cultivated by the household & $\$ 737^{* *}$ & $\$ 3,149$ & $\$ 117$ & $\$ 274$ & $\$ 620^{* *}$ \\
\hline Average walking distance to plots (minutes) & $3.60^{* * *}$ & 2.04 & 2.14 & 1.20 & $1.46^{* * *}$ \\
\hline $\begin{array}{l}=1 \text { if member of household is member of } \\
\text { village savings and loan association }\end{array}$ & 0.51 & 24.59 & 23.22 & 21.31 & $8.13^{* * *}$ \\
\hline $\begin{array}{l}\text { Walking distance to nearest extension officer } \\
\text { (minutes) }\end{array}$ & 32.05 & 145.66 & 45.51 & 122.15 & -13.46 \\
\hline
\end{tabular}

Note: The number of household-level observations is 169 tenants and 169 landlords. ***, **, and * denote statistical significance levels $1 \%, 5 \%$ and $10 \%$, respectively, from difference of means tests. 
Table 2: Input use and investment by plot ownership and cultivation status

\begin{tabular}{|c|c|c|c|c|c|c|}
\hline & \multicolumn{2}{|c|}{$\begin{array}{c}(1) \\
\text { Tenant's } \\
\text { Rented-in plot }\end{array}$} & \multicolumn{2}{|c|}{$\begin{array}{c}(2) \\
\text { Tenant's owner- } \\
\text { cultivated plots }\end{array}$} & \multicolumn{2}{|c|}{$\begin{array}{c}\text { (3) } \\
\text { Landlord's owner- } \\
\text { cultivated plots }\end{array}$} \\
\hline & Mean & $\mathrm{SD}$ & Mean & SD & Mean & SD \\
\hline \multicolumn{7}{|l|}{ Input use } \\
\hline Number of times the plot was weeded & 1.54 & $(0.79)$ & 1.49 & $(0.83)$ & 1.56 & $(0.83)$ \\
\hline 1=applied herbicide & $0.21^{\mathrm{a}}$ & $(0.41)$ & $0.24^{\mathrm{a}}$ & $(0.43)$ & 0.09 & $(0.28)$ \\
\hline $\mathrm{Kg}$ of inorganic fertilizer applied /ha & $221^{\mathrm{a}}$ & (227) & $225^{\mathrm{a}}$ & (227) & 152 & (203) \\
\hline 1=hybrid maize was main crop & $0.34^{\mathrm{b}}$ & $(0.47)$ & $0.43^{b, c}$ & $(0.50)$ & $0.34^{\mathrm{c}}$ & $(0.47)$ \\
\hline \multicolumn{7}{|l|}{ Investment } \\
\hline 1=Intercropped maize and legume & 0.21 & $(0.41)$ & 0.21 & $(0.41)$ & 0.26 & $(0.44)$ \\
\hline 1=Applied animal manure & $0.14^{\mathrm{d}, \mathrm{b}}$ & $(0.34)$ & $0.26^{\mathrm{d}}$ & $(0.44)$ & $0.21^{\mathrm{b}}$ & $(0.41)$ \\
\hline $1=$ Applied green compost & $0.07^{\mathrm{d}}$ & $(0.25)$ & 0.11 & $(0.31)$ & $0.15^{\mathrm{d}}$ & $(0.35)$ \\
\hline $1=$ Used minimum tillage & 0.05 & $(0.22)$ & $0.13^{\mathrm{e}}$ & $(0.34)$ & $0.13^{\mathrm{e}}$ & $(0.33)$ \\
\hline
\end{tabular}

Note: $\mathrm{N}=347$ in column 1, $\mathrm{N}=266$ in column 2, $\mathrm{N}=335$ in column 3; Bonferroni multiple comparison test used to test means among groups

$\mathrm{a}=$ statistically different from landlord cultivated plot (column 3) at $1 \%$ level, not different from each other

$\mathrm{b}=$ statistically different from each other at $5 \%$ level

$\mathrm{c}=$ statistically different from each other at $5 \%$ level

$\mathrm{d}=$ statistically different from each other at the $1 \%$ level

$\mathrm{e}=$ statistically different from tenant's rented-in plot (column 1) at $1 \%$ level, not different from each other. 
Table 3: Differences between landlord's owner-cultivated and rented-out plots

\begin{tabular}{|c|c|c|c|c|}
\hline & \multicolumn{2}{|c|}{$\begin{array}{c}\text { (1) } \\
\text { Landlord's } \\
\text { Owner-cultivated } \\
\text { plots }\end{array}$} & \multicolumn{2}{|c|}{$\begin{array}{c}\text { (2) } \\
\text { Landlord's } \\
\text { Rented-out plots }\end{array}$} \\
\hline & Mean & $\mathrm{SD}$ & Mean & SD \\
\hline $\begin{array}{l}=1 \text { if landlord views the soil as good } \\
\text { or very good }\end{array}$ & 0.45 & 0.50 & 0.47 & 0.50 \\
\hline $\begin{array}{l}=1 \text { if landlord perceives someone likely } \\
\text { or very likely to challenge tenure status of plot }\end{array}$ & 0.10 & 0.30 & 0.14 & 0.35 \\
\hline$=1$ if topsoil is acidic $(<5.2 \mathrm{pH})$ in top soil & 0.19 & 0.39 & 0.16 & 0.37 \\
\hline Soil organic matter $(\%)$ in top soil & 2.42 & 1.35 & 2.22 & 1.19 \\
\hline Phosphorus (ppm) in top soil & 37.19 & 23.35 & 38.27 & 22.76 \\
\hline$=1$ if fruit trees on plot & $0.42^{\mathrm{a}}$ & 0.50 & $0.25^{\mathrm{a}}$ & 0.44 \\
\hline
\end{tabular}

Note: $\quad \mathrm{N}=137$ in column $1, \mathrm{~N}=108$ in column 2

$\mathrm{a}=$ investment on plot is statistically different from each other at the $1 \%$ level 
Table 4. Factors affecting plot-level input use

\begin{tabular}{|c|c|c|c|c|}
\hline & (1) & (2) & (3) & (4) \\
\hline VARIABLES & $\begin{array}{l}\text { \# of times plot } \\
\text { was weeded }\end{array}$ & $\begin{array}{l}1=\text { applied } \\
\text { herbicide }\end{array}$ & $\begin{array}{c}\mathrm{kg} \text { of inorganic } \\
\text { fertilizer applied } \\
\text { /ha }\end{array}$ & $\begin{array}{l}1=\text { hybrid } \\
\text { maize was } \\
\text { main crop }\end{array}$ \\
\hline \multirow[t]{2}{*}{$=1$ if plot rented in $\&$ cultivated by tenant $\hat{\beta}_{1}$} & -0.04 & 0.07 & $61.01 * *$ & -0.03 \\
\hline & $(0.131)$ & $(0.047)$ & $(29.107)$ & $(0.059)$ \\
\hline \multirow[t]{2}{*}{$=1$ if plot owned $\&$ cultivated by tenant $\hat{\beta}_{2}$} & -0.03 & $0.08^{*}$ & $78.07 * * *$ & 0.08 \\
\hline & $(0.116)$ & $(0.047)$ & $(27.846)$ & $(0.061)$ \\
\hline \multirow{2}{*}{$\begin{array}{l}\text { education of household head in years of } \\
\text { schooling }\end{array}$} & -0.00 & $-0.01 * *$ & 3.04 & $0.01 *$ \\
\hline & $(0.010)$ & $(0.005)$ & $(2.624)$ & $(0.006)$ \\
\hline \multirow{2}{*}{$\begin{array}{l}\text { area owned by household pre-land } \\
\text { renting, in ha }\end{array}$} & 0.01 & 0.02 & -1.81 & 0.01 \\
\hline & $(0.032)$ & $(0.016)$ & (11.136) & $(0.021)$ \\
\hline \multirow{2}{*}{ Enumber of members in household } & -0.01 & 0.01 & $-14.91 * * *$ & -0.01 \\
\hline & $(0.022)$ & $(0.009)$ & $(5.402)$ & $(0.013)$ \\
\hline \multirow{2}{*}{$\begin{array}{l}\text { 总=1 if } \mathrm{HH} \text { head is female } \\
\text { 言 }\end{array}$} & 0.15 & -0.06 & 16.89 & -0.05 \\
\hline & $(0.154)$ & $(0.045)$ & $(28.820)$ & $(0.077)$ \\
\hline \multirow{2}{*}{ the of household head in years } & -0.00 & $-0.01 * * *$ & 0.33 & 0.00 \\
\hline & $(0.004)$ & $(0.002)$ & $(0.760)$ & $(0.002)$ \\
\hline \multirow{2}{*}{ Ssavings in USD*1000 } & 0.00 & -0.00 & 0.01 & -0.00 \\
\hline & $(0.000)$ & $(0.000)$ & $(0.030)$ & $(0.000)$ \\
\hline \multirow{2}{*}{ value of assets in USD*100 } & -0.00 & -0.00 & 0.00 & $-0.00 *$ \\
\hline & $(0.000)$ & $(0.000)$ & $(0.002)$ & $(0.000)$ \\
\hline \multirow[t]{2}{*}{ number of plots cultivated by household } & -0.02 & $0.03 * *$ & 2.31 & 0.01 \\
\hline & $(0.025)$ & $(0.014)$ & $(6.455)$ & $(0.014)$ \\
\hline \multirow{2}{*}{ E } & $0.003 *$ & -0.00 & 0.02 & -0.00 \\
\hline & $(0.001)$ & $(0.001)$ & $(0.517)$ & $(0.001)$ \\
\hline \multirow{2}{*}{$\begin{array}{l}\text { =1 if member of household is in a village } \\
\text { savings and loan association }\end{array}$} & 0.00 & -0.06 & 9.95 & 0.07 \\
\hline & $(0.106)$ & $(0.044)$ & $(22.386)$ & $(0.060)$ \\
\hline \multirow{2}{*}{$\begin{array}{l}\text { distance to the nearest ag. extension officer } \\
\text { from residence (walking minutes) }\end{array}$} & -0.00 & 0.00 & 0.05 & $0.0002 * *$ \\
\hline & $(0.000)$ & $(0.000)$ & $(0.099)$ & $(0.000)$ \\
\hline \multirow[t]{2}{*}{$\hat{\beta}_{1}-\hat{\beta}_{2}=0$} & -0.01 & -0.02 & -17.05 & $-0.11 * *$ \\
\hline & $(0.074)$ & $(0.026)$ & $(0.371)$ & $(0.040)$ \\
\hline rental-pair fixed effects & Yes & Yes & Yes & Yes \\
\hline R-squared & 0.017 & 0.103 & 0.047 & 0.021 \\
\hline observations & 948 & 948 & 948 & 948 \\
\hline
\end{tabular}

Note: The base category for comparing $\hat{\beta}$ estimates is a landlord's owner-operated plot(s).

Standard errors in parentheses; $* * *, * *$, and $*$ denote that the corresponding coefficients are statistically significant at the $1 \%, 5 \%$ and $10 \%$ level respectively. Models include a constant and district-level fixed effects. Districts are not completely collinear with the rental-pair location because we found four cases of tenants and landlord pairs residing in different districts. Number of observations $=948$, with 169 matched tenant-landlord pairs; $\hat{\beta}_{1}$ and $\hat{\beta}_{2}$ are compared to landlord's owner cultivated plot. 
Table 5: Factors affecting plot-level soil fertility investments

\begin{tabular}{|c|c|c|c|c|}
\hline & (1) & (2) & (3) & (4) \\
\hline VARIABLES & $\begin{array}{c}1=\text { Intercropped } \\
\text { maize and } \\
\text { legume }\end{array}$ & $\begin{array}{l}1=\text { Applied } \\
\text { animal manure }\end{array}$ & $\begin{array}{l}1=\text { Applied } \\
\text { green compost }\end{array}$ & $\begin{array}{c}1=\mathrm{Used} \\
\text { minimum } \\
\text { tillage }\end{array}$ \\
\hline \multirow{2}{*}{$=1$ if plot rented in $\&$ cultivated by tenant $\hat{\beta}_{1}$} & 0.04 & -0.05 & $-0.07 * *$ & -0.02 \\
\hline & $(0.048)$ & $(0.049)$ & $(0.034)$ & $(0.051)$ \\
\hline \multirow{2}{*}{$=1$ if plot owned $\&$ cultivated by tenant $\hat{\beta}_{2}$} & 0.08 & 0.06 & -0.02 & 0.03 \\
\hline & $(0.047)$ & $(0.054)$ & $(0.038)$ & $(0.051)$ \\
\hline \multirow{2}{*}{$\begin{array}{l}\text { education of household head in years of } \\
\text { schooling }\end{array}$} & -0.00 & -0.01 & 0.00 & -0.00 \\
\hline & $(0.005)$ & $(0.006)$ & $(0.004)$ & $(0.006)$ \\
\hline \multirow{2}{*}{$\begin{array}{l}\text { area owned by household pre land renting, in } \\
\text { hectares }\end{array}$} & -0.02 & 0.01 & -0.02 & 0.03 \\
\hline & $(0.020)$ & $(0.021)$ & $(0.012)$ & $(0.024)$ \\
\hline \multirow{2}{*}{ number of members in household } & $0.02 * *$ & $-0.02 * * *$ & -0.01 & 0.01 \\
\hline & $(0.009)$ & $(0.009)$ & $(0.007)$ & $(0.010)$ \\
\hline \multirow{2}{*}{$\frac{1}{b}=1$ if household head is female } & 0.06 & $-0.10^{*}$ & -0.00 & 0.01 \\
\hline & $(0.063)$ & $(0.059)$ & $(0.034)$ & $(0.046)$ \\
\hline \multirow{2}{*}{ fage of household head in years } & 0.00 & 0.00 & $0.00 *$ & 0.00 \\
\hline & $(0.001)$ & $(0.002)$ & $(0.001)$ & $(0.001)$ \\
\hline \multirow{2}{*}{ 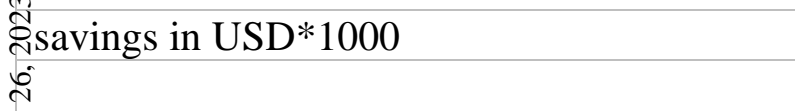 } & $0.00 *$ & $0.0002 *$ & 0.00 & 0.00 \\
\hline & $(0.000)$ & $(0.000)$ & $(0.000)$ & $(0.000)$ \\
\hline \multirow{2}{*}{ value of assets in USD*1000 } & -0.00 & -0.00 & $-0.008 * * *$ & $-0.01 * * *$ \\
\hline & $(0.000)$ & $(0.000)$ & $(0.000)$ & $(0.000)$ \\
\hline \multirow{2}{*}{ nets } & $-0.05 * * *$ & -0.01 & 0.00 & -0.01 \\
\hline & $(0.013)$ & $(0.018)$ & $(0.009)$ & $(0.013)$ \\
\hline \multirow{2}{*}{ Eplot distance from house (walking minutes) } & 0.00 & -0.00 & -0.00 & -0.00 \\
\hline & $(0.001)$ & $(0.001)$ & $(0.001)$ & $(0.001)$ \\
\hline \multirow{2}{*}{$\begin{array}{l}\mathbb{8}=1 \text { if member of household is in a village } \\
\text { onsavings and loan association }\end{array}$} & $0.07 *$ & 0.01 & 0.03 & 0.03 \\
\hline & $(0.042)$ & $(0.057)$ & $(0.042)$ & $(0.036)$ \\
\hline \multirow{2}{*}{$\begin{array}{l}\text { Odistance to the nearest ag. extension officer } \\
\text { from residence (walking minutes) }\end{array}$} & $0.0002 *$ & 0.00 & 0.00 & -0.00 \\
\hline & $(0.000)$ & $(0.000)$ & $(0.000)$ & $(0.000)$ \\
\hline \multirow[t]{2}{*}{$\hat{\beta}_{1}-\hat{\beta}_{2}=0$} & -0.04 & $-0.11 * * *$ & $-0.05 * *$ & $-0.05^{*}$ \\
\hline & $(0.028)$ & $(0.034)$ & $(0.022)$ & $(0.026)$ \\
\hline rental-pair fixed effects & Yes & Yes & Yes & Yes \\
\hline R-squared & 0.046 & 0.041 & 0.038 & 0.046 \\
\hline observations & 948 & 948 & 948 & 948 \\
\hline
\end{tabular}

Note: Standard errors in parentheses; $* * *, * *$, and * denote that the corresponding coefficients are statistically significant at the $1 \%, 5 \%$ and $10 \%$ level respectively. Models include a constant and district-level fixed effects. Districts are not completely collinear with the rental-pair location because we found four cases of tenants and landlord pairs residing in different districts. Number of observations $=948$, with 169 matched tenant-landlord pairs; $\hat{\beta}_{1}$ and $\hat{\beta}_{2}$ are compared to landlord's owner cultivated plot; models include a constant and district fixed effects 
Table 6: Factors affecting which plot the landlord decides to rent out

\begin{tabular}{|c|c|c|c|c|c|}
\hline $\begin{array}{l}\text { Dependent variable }=1 \text { if plot rented- } \\
\text { out, }=0 \text { if owner-cultivated }\end{array}$ & (1) & (2) & (3) & (4) & $(5)$ \\
\hline \multirow{2}{*}{$\begin{array}{l}=1 \text { if landlord views soil as good or } \\
\text { very good }\end{array}$} & 0.11 & & & & 0.02 \\
\hline & $(0.167)$ & & & & $(0.160)$ \\
\hline \multirow{2}{*}{$\begin{array}{l}=1 \text { if topsoil is acidic }(<5.2 \mathrm{pH}) \text { in } \\
\text { topsoil }\end{array}$} & & -0.05 & & & -0.04 \\
\hline & & $(0.156)$ & & & $(0.145)$ \\
\hline \multirow[t]{2}{*}{ organic matter $(\%)$ in topsoil } & & -0.07 & & & -0.06 \\
\hline & & $(0.042)$ & & & $(0.043)$ \\
\hline \multirow[t]{2}{*}{ phosphorus (ppm) in topsoil } & & 0.00 & & & 0.00 \\
\hline & & $(0.003)$ & & & $(0.003)$ \\
\hline \multirow[t]{2}{*}{ fruit trees on the plot } & & & $-0.49 * * *$ & & $-0.51 * * *$ \\
\hline & & & $(0.121)$ & & $(0.120)$ \\
\hline \multirow{2}{*}{$\begin{array}{l}=1 \text { if landlord perceives someone likely } \\
\text { to challenge tenure status of plot }\end{array}$} & & & & 0.29 & $0.33 *$ \\
\hline & & & & $(0.197)$ & $(0.182)$ \\
\hline landlord fixed effects & Yes & Yes & Yes & Yes & Yes \\
\hline R-squared & 0.004 & 0.018 & 0.097 & 0.016 & 0.137 \\
\hline observations & 245 & 245 & 245 & 245 & 245 \\
\hline
\end{tabular}

Note: Standard errors in parentheses; $* * *, * *$, and $*$ denote that the corresponding coefficients are statistically significant at the $1 \%, 5 \%$ and $10 \%$ level respectively. Models include a constant and district-level fixed effects. Districts are not completely collinear with the rental-pair location because we found four cases of tenants and landlord pairs residing in different districts. Number of observations $=245$, with 137 owner-operated plots and 108 rented-out plots; models include a constant and district fixed effects. 
${ }^{1} \mathrm{~A}$ key idea is that because more efficient farmers have higher marginal returns to cultivation than less efficient farmers, transfer of land via rental or sale transactions will make both actors better off if the transactions are economically efficient.

${ }^{2}$ In this article, a 'plot' is a field that may contain one or more sub-plots. In our context, the rental decision actually occurs at the sub-plot level, as within a plot, one or more sub-plots may be rented while other sub-plots may be owner-cultivated. For simplicity, we refer to all fields as plots in this article.

${ }^{3}$ One of the challenges associated with accurately estimating soil fertility and/or other impacts of land rental markets is that most studies in the region (and all of the studies mentioned above) severely underreported the activities of landlords. In fact, a recent article by Deininger, Savastano, and Xia (2017) used nationally representative LSMS-ISA data from six countries in SSA collected within the past five years to show that total area rented-out made up less than $50 \%$ of total area rented in all six countries (Ethiopia, Malawi, Niger, Nigeria, Tanzania, and Uganda). Furthermore, rented-out land made up less than $6 \%$ of rented in land in three of the six countries (Malawi, Nigeria, and Uganda). In Malawi, Lunduka, Holden, and $\varnothing$ ygard (2009) found only $8 \%$ of their sample were landlords, versus $20 \%$ who reported being tenants. The failure of most datasets to fully capture the landlord side of the rental market at best leaves out important details as to the landlords' intentions, and at worst biases any results and conclusions that are drawn from such incomplete datasets.

${ }^{4}$ Due to collinearity among these soil fertility measures, we end up using phosphorous, organic matter and pH in the empirical analysis.

${ }^{5}$ Village lists in Malawi were regarded as being accurate because they were used to determine how many input subsidy vouchers were given to a particular community and then to households within the community. Therefore, households had incentives to make sure they were included on the list.

${ }^{6}$ Tenants and landlords formed unique pairs in this analysis. If at tenant (landlord) had multiple landlords (tenants) then only the landlord (tenant) who owned (operated) the largest rented plot was found for interview. This was done for logistical purposes to keep the time and duration of the survey manageable.

${ }^{7}$ Due to collinearity we only used topsoil measures for phosphorous, soil organic matter, and pH. Other measures were dropped.

${ }^{8}$ We note that this variation is only useful in this context if renters have multiple plots with differing rental status. In our dataset, we have very few households with only a single plot. Summary statistics are provided in appendix A. ${ }^{9}$ Land may also be borrowed-in where one household lets another household cultivate their land with no money exchanged. For the purpose of this analysis, we consider borrowed land to be rented land at a zero price.

${ }^{10}$ We thank an anonymous reviewer for raising this point.

${ }^{11}$ This view is consistent with other studies which find that fruit trees on farms make important contributions to household consumption and income (e.g. Miller et al. 2017). An alternative view is that fruit trees planted by the landlord may strengthen security of a landlord's claims to land, and thus make renting out less subject to the risk of re-allocation by customary authorities. This view does not seem to be supported by our results. One reason underlying this may have to do with the uncertain age of the fruit trees in question, which may well pre-date the current landlord's association with the plot.

12 Most landlords in our sample said that they were motivated to rent out land by the need for cash, but this does not preclude the possibility that they were also more likely to rent out land which they were unable to cultivate themselves. The lack of labor and capital with which to farm has been a well-documented motivation for renting out land, particularly for female-headed households, elsewhere in the region (e.g. Holden and Ghebru 2016, Holden et al 2011, Holden et al. 2008, for Ethiopia). Furthermore, in Malawi, the relative scarcity of labor and capital resources, relative to landholding, was found to be positively associated with the likelihood of renting out land (Chamberlin and Ricker-Gilbert 2016). Nonetheless, we are unable to say whether or not a plot would have been cultivated by a landlord if she or he had not rented that plot out. 